Научная статья

УДК 1: $294.3(571.54)$

DOI: 10.18101/1994-0866-2021-4-32-40

\title{
БУДДИЗМ В МИРОВОЗЗРЕНИИ И НАЦИОНАЛЬНОМ ХАРАКТЕРЕ БУРЯТ
}

\section{(C) Серебрякова Юлия Александровна}

доктор философских наук, профессор

Бурятская государственная сельскохозяйственная академия имени В. Р. Филиппова Россия, 670024, г. Улан-Удэ, ул. Пушкина 8

serebr.yu.a@yndex.ru

\section{(c) Аякова Жаргал Аюшиевна}

доктор философских наук, доцент

Бурятская государственная сельскохозяйственная академия имени В. Р. Филиппова Россия, 670024, г. Улан-Удэ, ул. Пушкина, 8

azhargal@yndex.ru

\begin{abstract}
Аннотация. Важным фактором, оказавшим влияние на характер бурятского народа, является буддизм, всегда гибко взаимодействовавший с другими конфессиями региона проживания этого этноса, светскими властями, сложившимися ко времени распространения новой религии традиционными воззрениями, представлениями, нормами, практиками местного населения, адаптировав и инкорпорировав их в свою систему. Постепенно буддизм осознавался как мировая религия и национальная религия бурят и фактор их консолидации, что усилило воздействие на национальный характер фундаментальных принципов буддизма: добросердечие, терпение, сострадание ко всем живым существам, ответственность человека за все живое на земле, равенство всех людей, утверждение гуманистической миссии образования, лояльность к науке и др. Это способствовало формированию или укреплению таких черт характера бурят, как экологичность отношения к окружающему миру, миролюбие, доброжелательность, уважение к людям независимо от степени их близости или родства, этнической и религиозной принадлежности, гостеприимство, значимость семейных уз и традиций, стремление к знаниям, образованию и пр.
\end{abstract}

Ключевые слова: бурятский народ, национальный характер, черты характера, буддизм, дацан, современный буддизм, принципы буддизма, гуманность, личность.

\section{Для цитирования}

Серебрякова Ю. А., Аякова Ж. А. Буддизм в мировоззрении и национальном характере бурят // Вестник Бурятского государственного университета. Философия. 2021. Вып. 4. С. 32-40.

Характер бурятского народа выступает неким интегральным образованием, концентрированным воплощением исторически сложившихся устойчивых способов его поведения и типичных черт национальной психологии. В настоящее время актуальна проблема его дальнейшего исследования, имеющая не только познавательную ценность. Адекватное представление о собственном характере может способствовать успешному решению актуальных вопросов и верному определению стратегии дальнейшего развития этноса. 
Ю. А. Серебрякова, Ж. А. Аякова. Буддизм в мировоззрении и национальном характере бурят

Среди черт бурятского характера можно выделить те, которые во многом сформировались или укрепились под влиянием буддизма, его мировоззренческих оснований, социальных представлений, духовных и культурных ориентиров, в том числе этических норм, оказавшихся созвучными традиционным воззрениям, представлениям, нормам, выработанным бурятским народом и закрепившимся в его бытии и сознании ко времени принятия им буддизма.

Начало распространения буддизма в Забайкалье относят к середине XVII в. (хотя отдельные группы бурят были знакомы с ним с 16-го столетия), а в Предбайкалье - к концу XIX в. Этот процесс сопровождался прежде всего строительством дацанов как духовных центров, количество которых и их роль в местном обществе постоянно возрастали. Если в конце XVIII в. в Забайкалье насчитывалось 16, в середине XIX в. - 34, то в начале XX в. - уже более 40 дацанов, число лам в которых превышало 10 тыс. [1, с. 172, 367].

Локальный вариант буддизма проявлял гибкость во взаимодействии с другими конфессиями Байкальского региона, светскими властями, многие его служители выходили за рамки сугубо религиозных практик, старались учитывать запросы людей, демонстрировали понимание интересов мирян, общались с ними на их родном языке, помогали им, в том числе как врачеватели.

Дацаны стали образовательными центрами, где обучающиеся в течение значительного периода системно осваивали буддийское наследие, его философию, логику, этику, историю, тибетскую медицину, старомонгольскую письменность и другие дисциплины, пользовались библиотеками. Как отмечает Н. Д. Болсохоева, «традиции тибетского классического образования прочно укоренились в этнической Бурятии» [2, p. 49].

Эта деятельность стала ответом на потребность в знаниях, стремление все большего числа людей к просвещению, рост их интеллектуальных запросов. Увеличение числа грамотных способствовало развитию духовной сферы жизни того общества. При этом буддийская система приобщения к знаниям функционировала параллельно с просвещением на русском языке.

Помимо основательной исследовательской и образовательной деятельности в дацанах копировались монгольские и тибетские книги и брошюры, издавались оригинальные труды, создавались произведения изобразительного, прикладного и других видов искусства. «В состав Российского государства буряты вошли с ценностями буддийской религии и культуры, освоив вместе с ней письменность, образование, науку, медицину, литературу и искусство», - констатируют авторы «Истории Бурятии» [1, с. 545].

Закономерно, что буддизм впитал в себя элементы воззрений и практик местного населения, опираясь на определенные черты национального характера, способствовавшие распространению этого вероучения в Бурятии. Со временем буддизм все более осознавался как мировая религия и вместе с тем как национальная религия бурят, фактор их консолидации, что также обусловило его влияние на характер бурятского народа.

Под влиянием буддизма укрепилась такая черта национального характера, как экологичность отношения бурят к окружающему миру, восходящая не только к кочевому образу жизни, приоритету животноводства в хозяйственной деятельности и шаманистским верованиям, но и во многом обусловленная воздей- 
ствием одного из важнейших принципов буддизма, в том числе тибетомонгольского варианта махаяны, бытующего в Бурятии, - сострадания ко всем живым существам и вообще ко всему живому. «Главный акцент в махаяне сделан не на личном спасении, а на спасении другого, точнее, всего живого на земле, - пишет М. Ф. Альбедиль. - Высшая цель для приверженцев махаяны - не нирвана, а состояние бодхисатвы, существа, суть которого - в его любящем сердце, и объект этой любви - весь мир» [3, с. 74].

Не случайно содержанием одной из основных заповедей Будды является благоговение перед жизнью во всех ее ипостасях, запрет наносить какой-либо вред живым существам, которые обладают переживаниями и ощущениями и считаются равными друг другу. Поэтому не приемлемо принесение в жертву одного живого существа ради пользы другого.

Традиционные представления, верования и исконные нормы поведения бурят с приходом буддизма постепенно были адаптированы им и органично включены в систему местного варианта буддизма. При этом традиционные экологические представления бурят совпадали с аналогичными установлениями новой религии. Как и все монгольские народы, они «прекрасно осознавали, что без правильного и бережного взаимодействия с природой и природными стихиями, которые представляют собой неуправляемые человеком тонкие энергетические структуры, они не смогут реализовать созданную ими на протяжении веков целостную стратегию выживания» [4, с. 99].

Современный буддизм неизменно подчеркивает нравственную ответственность человека за все живое на земле. Так, Его Святейшество Далай-лама IV учит, что разрушительное и излишнее использование природы есть результат людского неведения, жадности, расточительности и отсутствия благоговейного отношения ко всему живому. Достижение же успеха в деле сохранения и защиты природы зависит, по его мнению, от изменения характера потребления, сотрудничества на мировом уровне, взаимоуважения и доверия между всеми сторонами [5, c. 81-82].

Для буддиста принцип истинного сострадания имеет фундаментальный характер. Он не только не отрицает страдания и не избегает его, но и рассматривает различные его уровни, проникается им, концентрируется на нем, чтобы уменьшить страдание, причиняемое человеком. Признание страдания приводит к стремлению освободиться от него.

Далай-лама IV распространяет сострадательное отношение и чувство универсальной ответственности на весь мир, в том числе и на природу, воспринимая ее в неразрывной связи с человечеством, человеческим разумом и его добрым сердцем и утверждая, что, нарушая равновесие в природе, люди будут страдать. По его мнению, сама природа человека неотделима от любви и сострадания, способности к сопереживанию. С недостатком доброты и сострадания Его Святейшество связывает глобальные проблемы современной цивилизации и верит в то, что «сострадание - не только путь эволюции человека, но и путь самого выживания человеческого существа» [6, с. 100-101].

Один из авторитетных деятелей российского буддизма настоятель СанктПетербургского дацана Б. Б. Бадмаев также призывает «сострадательно воспринимать все поступки живых существ» [7, с. 51]. Сострадание ко всем живым су- 
ществам и забота о счастье других - это качества совершенной, просветленной личности [8, с. 38].

Очевидно, что благоговейное отношение буддизма к природе, сострадательное отношение к ней и осознание ответственности за состояние окружающего мира повлияло на высокий уровень экологической культуры бурят и укрепило соответствующую черту национального характера.

Понятие высокой ответственности неотделимо от содержания буддийской доктрины о личности, от деяний и сознания которой зависит как состояние ее души, личная судьба и будущее ее потомков, так и совершенствование окружающего мира. По сути, буддизм предлагает путь становления личности, преодоления эгоизма и постоянного нравственного совершенствования.

Благодаря распространению буддизма в Бурятии, как пишут Ю. Ц. Тыхеева и О. А. Шишмарева, у жителя этой территории «формируется представление о самом себе как личности... человек начинал ощущать равенство всех людей... Буддийское учение призывало человека к определенной системе поведения, этическим принципам, которым нужно было неукоснительно следовать ... эти этические принципы обращались к самому человеку, подчеркивая его личностные черты» [9, с. 202].

В полной мере соотносится с буддийскими принципами гуманности, добросердечия, личной ответственности за свои деяния такое качество бурятского характера, как миролюбие, которое тесно сопрягается с отсутствием агрессивности, терпимостью, уживчивостью, доброжелательностью, вниманием и уважением к окружающим, в том числе к ближайшим и дальним соседям, представителям иных народов, верований, способностью к истинной дружбе, гостеприимством и т. п.

Еще Н. А. Бестужев писал о стремлении бурят уклониться от конфликта: «Бурят не драчлив, не задорен, хотя между ними бывают схватки. От русского он обыкновенно отходит прочь при малейшем поводе к ссоре» [10, с. 130].

Декабрист также выделял такую черту национального характера, как обязательность бурят в возвращении взятых в долг у других людей денег или скота: «...как бы ни был несостоятелен ваш должник, он никогда не отопрется от долга; он будет вам платить или зарабатывать многие годы, но не откажется от своего обязательства» [10, с. 129]. Полагаем, что эта черта показывает меру ответственности личности за свое поведение, является свидетельством внимательного и уважительного отношения к окружающим.

Особенно часто и подробно в имеющихся публикациях описывается гостеприимство бурятского народа, показывающее его коллективизм, радушие, щедрость, открытость, коммуникабельность и другие качества проявляющих его людей. Гость рассматривается как ценность, источник радости, «особый, драгоценный мир, который требует уважения и неприкосновенности» [11, с. 305]. Самим своим появлением он оказывает честь хозяевам, которые стремятся принять его с искренним радушием, почтением и соблюдением всех соответствующих ритуалов.

Гостеприимство дает прекрасную возможность проявить, в частности, такую общечеловеческую и буддийскую добродетель, как щедрость, стремление делиться с другими, к развитию и культивированию которой призывал Будда. Она 
столь же важна для духовного роста, как и другие добродетели. Поэтому в буддийских текстах детально анализируются суть, смысл дарения и его типы.

Современный буддизм рассматривает щедрость не только как реализацию внутреннего побуждения личности, но и как импульс к развитию ее интеллекта и творческих способностей. Б. Б. Бадмаев утверждает, что «делиться с другими это одна из наших внутренних обязанностей, потому что, не оставляя себе ничего, мы заставляем наш ум думать и развивать свои творческие способности, чтобы изыскать средства к собственному существованию и тем самым получить возможность вновь сеять добро» [7, с. 55].

Одним из качеств национального характера является терпимость бурят к иноверцам, людям иных культур, которая с течением времени приобрела форму межэтнической и межконфессиональной толерантности: «Во внутриэтнических отношениях буряты всегда проявляли коллективизм, взаимопомощь, преданность своему роду, которые позже распространились и на представителей других старожильческих народов, особенно вследствие сближения всех сфер их деятельности и межэтнического смешения» $[12$, с. 127].

Миролюбивые отношения между этносами Бурятии формировались в процессе постепенной взаимной адаптации друг к другу представителей различных по многим параметрам общностей, однако немалую роль в этом сыграли мировые религии, буддизм и христианство, основанные на началах гуманности, добра, терпения, прощения. Не подлежит сомнению, что принадлежность бурят к буддизму способствовала укреплению толерантности к представителям иных народов.

Буддизм исходит из фундаментального равенства людей. В поисках счастья и избегания страданий все люди абсолютно одинаковы и, следовательно, равны, и принятие этого утверждения порождает у них естественное чувство близости даже по отношению к незнакомцам; разделяющие людей факторы всегда более поверхностны, чем объединяющие. Опираясь на исследования генома, Его Святейшество пишет, что «расовое отличие составляет лишь крошечный фрагмент нашей генетической структуры, преобладающая часть которой является общей для всех нас» [5, с. 34-35].

Духовный лидер буддистов Его Святейшество Далай-лама XIV настойчиво призывает свою огромную аудиторию «жить гармонично, дружно», рассматривая другого как «нечто драгоценное и почитаемое ..., помогать другим и делиться с ними» $[6$, с. 42$]$.

К одному из основополагающих качеств бурятского характера относится значимость семьи, предполагающая почтение к родителям, особенно бережное отношение к детям, уважение родственных уз в целом и т. Д. Действенная забота о родителях взрослых детей проявляется в их совместном проживании. «У бурят считалось недопустимым, чтобы старики-родители, имея детей, жили отдельно от них. Дети были обязаны обеспечить им спокойную старость, а затем похоронить их достойным образом ... » [13, с. 181].

На вечные общечеловеческие ценности, в том числе и на исключительную близость родителей и детей, постоянно обращает внимание и буддизм. Помощь и забота, проявляемая родителями, служат их детям примером бескорыстной любви, которую буддист должен питать ко всем окружающим. 
Ю. А. Серебрякова, Ж. А. Аякова. Буддизм в мировоззрении и национальном характере бурят

Идеалом любви, самым сокровенным в буддийских текстах называется любовь матери к новорожденному и к своему единственному ребенку. Благодаря матери, ее огромной любви и заботе человек становится на путь добра и сострадания. «Новорожденные дети начинают вскармливаться материнским молоком. Это первый урок сострадания и любви. По своей природе принятие молока от своей матери является само по себе уроком человеческих отношений, базирующихся на любви. Мы должны стараться поддерживать этот дух» [6, с. 101].

Далай-лама XIV очень тепло вспоминает о своей матери, нежной, терпеливой, добросердечной безграмотной жены простого земледельца, которая была его первым учителем сострадания и «лучшим примером человека, в глубочайшей степени пропитанного духом сострадания ... я не могу припомнить ни одного случая, когда бы моя мама потеряла терпение хоть с кем-то. Она была удивительно добрым человеком не только по отношению к своим детям, но и по отношению ко всем встречным» [5, с. 49].

Говоря о необходимости установления и поддержания гармоничных отношений в обществе, авторы буддийских сочинений используют такие понятия, как «братья», «сестры», «собрат», призывая к пониманию того, что другие люди являются нашими братьями и сестрами, утверждая необходимость братской и сестринской любви, благотворности семейных связей. «Если в семье существует атмосфера сострадания, то это благотворно не только для родителей, но и для нового поколения», - считает Далай-лама XIV, отмечая, что семейным узам и семейной гармонии в традиционной Азии уделялось большое внимание $[6$, с. 101 , 141].

Примечательной чертой бурятского характера является стремление к знаниям, образованию, в разных аспектах раскрытое Н. А. Бестужевым, Н. Г. Гариным-Михайловским, А. И Терменом, М. Н. Хангаловым, Н. М. Ядринцевым, А. Штернбергом, В. И. Затеевым и другими авторами.

Следует отметить, что это качество часто отличалось действенностью, выражавшейся в тяге детей к учебе, в довольно массовых настойчивых индивидуальных просьбах родителей о принятии их детей в учебные заведения, в многочисленных ходатайствах общественности об открытии школ, училищ, библиотек, иных культурных учреждений, в той активности, которую население проявляло в организации и проведении сбора пожертвований на образовательные и культурные цели.

Ранее отмечалась весомость образовательной деятельности буддизма, коренящаяся в понимании его гуманистического предназначения. В сочинениях буддийских авторов часто обсуждаются вопросы образования, в том числе роль учителя в этом процессе. Не считая себя специалистом в области педагогики, Его Святейшество дает единственный совет: «помнить, что при обучении этической осознанности и внутренним ценностям решительно недостаточна лишь передача знаний; первостепенную важность имеет и обучение личным примером» [5, c. 85].

Отсюда следует высокая, в глобальном масштабе, оценка им миссии учителя. Учителя, говорит Его Святейшество Далай-лама XIV, «должны гордиться собою ... ибо выполняют работу, которая не только повышает уровень знаний обучае- 
мых, но и повлияет на всю их последующую жизнь. Это их вклад в будущее человечества» $[5$, с. 86$]$.

Очевидно, в данном случае имеет место совпадение одной из черт бурятского характера с присущим буддизму обоснованным позитивным отношением к знаниям и образованию.

Немало внимания исследователи, в том числе Н. А. Бестужев, М. К. Кюхельбекер, Ц. Жамцарано, А. Штернберг, В. И. Антонов, а также писатели (Н. Г. Гарин-Михайловский, Ч. Цыдендамбаев, А. Бальбуров, В. Митыпов, Д. Эрдынеев, Г. Т. Башкуев и другие), уделяют внимание интеллектуальным, творческим способностям бурят. Более подробно этот вопрос рассматривается в одной из последних по времени работ [14].

Особенностью буддизма является его лояльность к науке. Современный буддизм выдвинул положение не только о полезности новых идей и знаний, но и о необходимости для буддийской доктрины учитывать научные открытия и достижения $[6$, с. $140 ; 15$, с. 19]. Сам лидер современного буддизма показывает пример глубокого освоения им научных достижений, в том числе новейших.

Более того, им признается и доказывается связь науки и духовности, общность их целей по улучшению человеческой жизни и достижению благополучия людей [15, с. 12, 206].

При анализе возможности соотнесения буддизма с научной парадигмой С. П. Нестеркин, признавая специфичность его источников познания, отмечает использование им для доказательства своих положений «методологии и процедуры, практически идентичной научной». Этот автор указывает и на роднящий буддизм с наукой дух критики - сам Будда призывал последователей критически исследовать его учение, и на принятие буддизмом идей детерминизма и эволюции, нашедших выражение в законах кармы и совершенствующего движения, и на параллелизм буддийской мысли и многих концепций современной науки, и на факты плодотворного сотрудничества буддистов с учеными [16, p. 40-41].

В истории Бурятии такое сотрудничество имело место в течение многих исторических эпох и проявилось как в изысканиях крупных ученых, которые одновременно были видными представителями буддизма, так и в деятельности нескольких поколений научной интеллигенции, непротиворечиво сочетавшей верность истине с принадлежностью к буддизму или лояльным к нему отношением.

Итак, влияние наряду с иными факторами буддизма, с его институтами, в течение длительного времени ведущими широкую исследовательскую, образовательную, издательскую и иную деятельность, на формирование интеллектуальной активности бурят вполне очевидно.

Таким образом, несмотря на перипетии исторического развития, бурятский народ выработал и сохранил такие важные черты своего национального характеpa, как экологичность отношения к окружающему миру, миролюбие, отсутствие агрессивности, терпимость, уживчивость, доброжелательность, внимание и уважение к окружающим, в том числе к представителям иных народов и верований, способность к истинной дружбе, гостеприимство, щедрость, значимость семьи и семейных уз, стремление к знаниям, интеллектуально-креативная активность и др. Часть их в силу совпадения с качествами национального характера еще более укрепилась в сознании и практиках этноса, а некоторые сформировались под 
Ю. А. Серебрякова, Ж. А. Аякова. Буддизм в мировоззрении и национальном характере бурят

влиянием таких принципов буддизма, как любовь, добросердечие, терпение, сострадание ко всем живым существам, нравственная ответственность человека за все живое на земле, равенство всех людей, стремление делиться с другими, утверждение гуманистического предназначения образования, лояльность к науке и др.

Литература

1. История Бурятии: в 3 т. Т. 2. XVII - начало XX в. Улан-Удэ: Изд-во БНЦ СО РАН, 2011. 624 с. Текст: непосредственный.

2. Болсохоева Н. Д. Образовательная система бурятских манба дацанов // International Relations Among Developing Countries. Ulaanbaatar: Bimbu-Sen Press, 2008. P. 49-58. Текст: непосредственный.

3. Альбедиль М. Ф. Буддизм. Санкт-Петербург: Питер, 2006. 208 с. Текст: непосредственный.

4. Абаева Л. Л. Буддийская теория сострадания и всеобщей ответственности в монгольском мире // Вестник Бурятского государственного университета. Философия, социология, политология, культурология. 2015. Вып. 14. С. 98-102. Текст: непосредственный.

5. Далай-лама XIV Тензин Гьяцо. Вне религии: этика для целого мира / под редакцией С. Гинзбурга; перевод с английского А. Морозова. Новосибирск: Дже Цонкапа, 2013. 156 с. Текст: непосредственный.

6. Далай-лама XIV Тензин Гьяцо. Гармония миров: диалоги о деятельном сострадании / перевод с английского Ф. Маликова. Новосибирск: Ясный свет, 1995. 176 с. Текст: непосредственный.

7. Бадмаев Б. Б. Лекции по философии и практике буддизма / сост. Ю. В. Болтач. Санкт-Петербург: Гиперион, 2009. 224 с. Текст: непосредственный

8. Аякова Ж. А., Серебрякова Ю. А. Буддийская этика: счастье как основная цель // Вестник Бурятского государственного университета. Философия. 2021. Вып. 1. С. 35-45. Текст: непосредственный.

9. Тыхеева Ю. Ц., Шишмарева О. Н. Человек в буддийской доктрине // Буддийская культура: история, источниковедение, языкознание и искусство: VI Доржиевские чтения. Санкт-Петербург: Нестор-История, 2011. С. 196-203. Текст: непосредственный.

10. Бестужев Н. А. Гусиное озеро // Декабристы о Бурятии. Статьи, очерки, письма. Улан-Удэ: Бурят. кн. изд-во, 1975. С. 63-136. Текст: непосредственный.

11. Лыгденова Т. Н. Культурные традиции как основа полиэтнического общества Байкальского региона // Буддийская культура: история, источниковедение, языкознание и искусство: ІІІ Доржиевские чтения. Санкт-Петербург: Нестор-История, 2009. С. 304-310. Текст: непосредственный.

12. Чимитова И. 3. Межэтническая толерантность и согласие в современном российском обществе: региональный аспект. Улан-Удэ: Изд-во БГСХА им. В. Р. Филиппова, 2021. 176 с. Текст: непосредственный.

13. Басаева К. Д. Семья и брак у бурят. Улан-Удэ: Бурят. кн. изд-во, 1991. 192 с. Текст: непосредственный.

14. Серебрякова 3. А., Серебрякова Ю. А. Об интеллектуально-креативной составляющей бурятского характера // Вестник Бурятского государственного университета. Философия. 2021. Вып. 2. С. 70-76. Текст: непосредственный.

15. Далай-лама XIV Тензин Гьяцо. Вселенная в одном атоме. Наука и духовность на служении миру. Элиста: Океан мудрости, 2012. 208 с. Текст: непосредственный 
16. Нестеркин С. П. Некоторые проблемы рецепции буддизма в российской культуpe // International Relations Among Developing Countries. Ulaanbaatar: Bimbu-Sen Press, 2008. P. 32-43. Текст: непосредственный.

Статья поступила в редакицию 13.09.2021; одобрена после рещчензирования 04.10.2021; принята к публикации 15.11.2021.

\title{
BUDDHISM IN THE WORLDVIEW AND NATIONAL CHARACTER OF THE BURYATS
}

Yulia A. Serebryakova

Dr. Sci. (Philos.), Prof., Filippov Buryat State Agricultural Academy

8 Pushkina St., Ulan-Ude 670024, Russia

serebr.yu.a@yndex.ru

\author{
Zhargal A. Ayakova \\ Dr. Sci. (Philos.), A/Prof., \\ Filippov Buryat State Agricultural Academy \\ 8 Pushkina St., Ulan-Ude 670024, Russia \\ azhargal@yndex.ru
}

Abstract. An important factor that influenced the character of the Buryat people was Buddhism, which had always flexibly interacted with other confessions of the region, the secular authorities, the traditional views, ideas, norms, practices of the local population by adapting and incorporating them into its own system. Gradually Buddhism was perceived as a world religion and national religion of the Buryats, a factor of their consolidation, which strengthened the impact of the fundamental principles of Buddhism, such as kindness, patience, compassion for all living beings, human responsibility for all life on earth, equality of all people, the humanistic mission of education, loyalty to science, etc., on the national character. This contributed to the development of the following character traits of the Buryats: environmental friendliness to the world around them, peacefulness, benevolence, respect for people regardless of their kinship, ethnic and religious affiliation, hospitality, importance of family ties, and traditions, desire for knowledge, education, etc.

Keywords: the Buryat people, national character, character traits, Buddhism, datsan, modern Buddhism, principles of Buddhism, humanitas, personality.

\section{For citation}

Serebryakova Yu. A., Ayakova Zh. A. Buddhism in the Worldview and National Character of the Buryats. Bulletin of Buryat State University. Philosophy. 2021; 4: 32-40.

The article was submitted 13.09.2021; approved after reviewing 04.10.2021; accepted for publication 15.11.2021. 